\title{
Ecosystem structure and trophic analysis of Angolan fishery landings
}

\author{
RONALDO ANGELINI ${ }^{1,2}$ and FILOMENA VAZ-VELHO ${ }^{3}$ \\ ${ }^{1}$ Departamento de Engenharia Civil, Universidade Federal do Rio Grande do Norte, campus Universitário, \\ CEP 59072-970, Natal, RN, Brazil. E-mail: ronangelini@yahoo.com.br \\ ${ }^{2}$ Marine Research Institute and Zoology Department, University of Cape Town, Rondebosch 7701, \\ Cape Town, South Africa. \\ ${ }^{3}$ Instituto Nacional de Investigação Pesqueira, Rua Mortala Mohamed Ilha de Luanda, CP 2601 Luanda, Angola.
}

\begin{abstract}
SUMMARY: Information on the mean trophic level of fishery landings in Angola and the output from a preliminary Ecopath with Ecosim (EwE) model were used to examine the dynamics of the Angolan marine ecosystem. Results were compared with the nearby Namibian and South African ecosystems, which share some of the exploited fish populations. The results show that: (i) The mean trophic level of Angola's fish landings has not decreased over the years; (ii) There are significant correlations between the landings of Angola, Namibia and South Africa; (iii) The ecosystem attributes calculated by the EwE models for the three ecosystems were similar, and the main differences were related to the magnitude of flows and biomass; (iv) The similarity among ecosystem trends for Namibia, South Africa and Angola re-emphasizes the need to continue collaborative regional studies on the fish stocks and their ecosystems. To improve the Angolan model it is necessary to gain a better understanding of plankton dynamics because plankton are essential for Sardinella spp. An expanded analysis of the gut contents of the fish species occupying Angola's coastline is also necessary.
\end{abstract}

Keywords: Ecopath with Ecosim, fishery management, marine ecosystem, Sardinella, trophic level.

RESUMEN: ESTRUCTURA DEL ECOSISTEMA Y ANÁLISIS TRÓFICO DE DESEMBARQUES PESQUEROS EN ANGOLA. - El nivel trófico de los desembarques pesqueros de Angola y el modelo Ecopath con Ecosim (EwE), fueron utilizados para examinar la dinámica de la pesquería de Angola. Los resultados fueron comparados con los ecosistemas de Namibia y de Sudáfrica, con quienes se comparte algunas de las poblaciones de peces. Los análisis permiten concluir que: i. El nivel trófico promedio de los desembarques en Angola no disminuyó; ii. Existe una correlación significativa entre los desembarques de Angola, Namibia y Sudáfrica; iii. Los atributos del ecosistema (EwE) para los tres ambientes fueron muy similares; iv. El patrón similar de desarrollo de los ecosistemas, implica que es necesario mantener estudios conjuntos para las poblaciones de peces y de sus ecosistemas entre las tres regiones. Para una mejora del modelo de Angola se requiere de una mejor comprensión de la dinámica del plancton, que representa una fuente esencial para Sardinella spp., como también de un detallado análisis de los contenidos estomacales de las especies de la región.

Palabras clave: Ecopath con Ecosim; ecosistema marino, gestión pesquera, nivel trófico, Sardinella.

\section{INTRODUCTION}

African fisheries play an important role in food security and good nutrition on the continent, and supply up to $60 \%$ of the population's protein intake in some sub-Saharan countries (Béné and Heck, 2005). In the Benguela ecosystem, South Africa, Namibia and Angola all actively exploit their resources. Currently, fisheries represent almost 9\% of the GDP (gross domestic product) in Namibia, $4 \%$ in Angola and $0.5 \%$ in South Africa. The annual landings are some $214000 \mathrm{t}$ in Angola, $509000 \mathrm{t}$ in Namibia and $617000 \mathrm{t}$ in South Africa (FAO, 2006).

The Namibian and western South African coastlines border the true Benguela coastal upwelling ecosystem, which has much higher biological production than that 
found in tropical areas, such as off most of Angola (Coll et al., 2006). The Angolan marine ecosystem is under the influence of two major current systems: the south-flowing warm Angolan Current and the northflowing cold Benguela Current. These two currents meet between 14 and $17^{\circ} \mathrm{S}$ at the Angola-Benguela front, impacting the whole water column and influencing the spatial distributions and diversity of the flora and fauna (Sumaila et al., 2005; Pichevin et al., 2005). The Angola Current is characterized by high diversity and low productivity, and it supports large populations of sardinellas, sciaenids and Dentex spp. At the north of the front, Sardinella aurita is associated with cold water, whereas Sardinella maderensis is found in warmer water, although Benguela-Niño warming events can invert this distribution (Binet et al., 2001). Sardinella spp. together with Trachurus spp. constitute Angola's most commercially important fish species.

Similar to other upwelling systems (Schwartzlose et al., 1999), the northern end of Benguela supports large populations of pelagic fish, mainly Cunene horse mackerel (Trachurus cunene), Cape horse mackerel (Trachurus capensis), big-eyed dentex (Dentex macroptlamus) and Cape hake (Merluccius capensis). Southern Benguela landings are dominated by $M$. capensis and its deeper-water congener M. paradoxus, small pelagic fish such as sardine Sardinops sagax, anchovy Engraulis encrasicolus, Cape horse mackerel, and larger predatory pelagic species, such as snoek $T h$ yrsites atun (Shannon et al., 2008).

Despite its relatively small landings, the Angolan fisheries employ more than 30000 people, almost twice the number employed in Namibia (Batty et al., 2005). Contributing to this number is the fact that Angolan small-scale fishery activities are spread widely along the country's entire coastline (Duarte et al., 2005). Comprehensive information on the fishery dynamics off Angola is therefore fundamental to ensuring the maintenance of both jobs and landings.

Recently, several indicators have been applied in fishery management to monitor the status of fisheries (Shannon et al., 2009). For instance, the mean trophic level $(T L m)$ of landings has been used to evaluate the impact of overexploitation on marine fish stocks (Pauly et al., 1998). Internationally too, there are ongoing efforts to develop a more holistic ecosystem-based approach to resource management, with the objective of providing a basis for implementing effective multispecies fisheries management (Griffis and Kimball, 1996; Caddy and Cochrane, 2001; Worm et al., 2006). Ecopath with Ecosim (EwE) software (Christensen and Pauly, 1992; Walters et al., 1997) has been used to study fisheries in many African ecosystems and to define strategies for their exploitation and management (Heymans et al., 2004; Shannon et al., 2004a; Vosloo, 2004; Moloney et al., 2005).

Information that is fundamental for supporting the ecosystem approach includes a data assessment for quantifying the interchange of energy and biomass among biotic components. In Angola, information on the gut contents of the fish stocks and the non-fish compartments is not available. Moreover, the collection of fishery statistics was hampered for two decades by internal conflict, and many of the data from small-scale fisheries sampling have been irretrievably lost (Duarte et al., 2005). Nowadays, the fishery department of the Angolan government promotes all efforts to collect fishery data because research surveys are currently the basis for estimating the stock status and establishing the total allowable catch, TAC (VazVelho et al., 2006).

The main aim of this paper is to examine longterm changes in the trophic level of fishery landings in Angola and to test whether the mean trophic level of Angolan landings has declined over time. Using the available information, a mass-balance eco-trophic model was constructed with Ecopath with Ecosim (EwE) for the Angolan marine ecosystem. The model describes community structure and quantifies biomass distribution and flows. Finally, the outputs of the EwE models of Namibia (northern Benguela) and South Africa (southern Benguela) are compared with our preliminary model for Angola, using overall ecosystem attributes.

\section{MATERIALS AND METHODS}

The study area is located between latitudes $5^{\circ}$ and $17^{\circ} 15^{\prime} \mathrm{S}$ (the latter the mouth of the Kunene River) along Africa's southwest coast. Angola's coastline is $1650 \mathrm{~km}$ long, and $330000 \mathrm{~km}^{2}$ of continental shelf lies within Angola's Economic Exclusive Zone (EEZ). The modelling results presented here cover a region of $\sim 500000 \mathrm{~km}^{2}$, the total area exploited by Angolan fishing activities (Duarte et al., 2005).

To analyse the dynamics of the landings, the TLm for 40 species was calculated using the trophic level presented in FishBase (Froese and Pauly, 2007; Appendix 1). These 40 form a subset of the 185 recognized Angolan stocks (FAO, 2000, 2006). Landings data were obtained in FishStat Plus (FAO, 2000) and refer to the period from 1950 to 2003 (FAO, 2006). Two Angolan landing areas are included: the southeast Atlantic, which accounts for $99.5 \%$ of the national landings and the central-east Atlantic, which has never supplied $>0.5 \%$ of the annual landings.

Mean trophic levels $(T L m)$ of the landings were estimated for each year and correlated with catches (on a $\log$ scale) using a Spearman rank correlation $\left(\mathrm{r}_{\mathrm{s}}\right)$. The relevance of the main top predators was evaluated by calculating the annual TLm for the species with trophic levels (TL) $>3.3$. The relative importance of Sardinella spp. and Trachurus spp. (the main landings in Angola, see above) was analysed with respect to the total landings. Changes in the TLm and landings were compared among Angola, South Africa and Namibia using the same data source (FAO, 2000, 2006) in order to compare the trends in the three countries. 


\section{Model}

The foodweb model for Angola's marine ecosystem was constructed using Ecopath with Ecosim (EwE) software (Christensen and Pauly, 1993). EwE is based on work developed by Polovina (1984) aimed at estimating the biomass and consumption of various elements of an aquatic ecosystem, and it uses network theory to analyse flows among the elements of an ecosystem (Ulanowicz, 1986). A basic requirement of mass-balance Ecopath models is that the input to each group is equal to the output (equilibrium conditions). A series of biomass budget equations are then determined for each group as Production - all predation on each grouping - non-predatory mortality - all exports $=0$. The resulting budget equations are transformed into simultaneous equations following

$0=B_{i} \times P B_{i} \times E E_{i}-\mathrm{Y}_{i}+\sum_{j}\left(B_{j} \times Q B_{j} \times D C_{j i}\right)$,

where $B_{i}$ is the biomass of species $i, P B_{i}$ the production/biomass ratio of $i$ that equates to the total mortality rate $\left(Z_{i}\right), E E_{i}$ the ecotrophic efficiency, i.e. the fraction of production of $i$ that is consumed, $Y_{i}$ the yield of $i$ or its catch by weight, $B_{j}$ the biomass of predator $j, Q B_{j}$ the food consumption per unit of biomass for consumer $j$ and $D C_{j i}$ is the fraction of $i$ in the diet of $j$.

Equation (1) was modified (see Walters et al., $1997)$ to include a routine (Ecosim) formulation that permits foodweb dynamics to be simulated and can be used to investigate fisheries under several management scenarios:

$\mathrm{d} B_{i} / \mathrm{d} t=g_{i} \times \sum_{j} Q_{j i}-\sum_{j} Q_{i j}+I_{i}-\left(M O_{i}+F_{i}+e_{i}\right) \times B_{i}$,

where $\mathrm{d} B_{i} / \mathrm{d} t$ is the change in biomass of group $I, g_{i}$ the net growth efficiency, $Q_{j i}$ the consumption of group $j$ by group $I, n$ the number of functional groups, $Q_{i j}$ the consumption of group $i$ by group $j, I_{i}$ the extent of immigration of group $i, M O_{i}$ the non-predation rate of natural mortality of group $I, F_{i}$ the fishing mortality on group $I, e_{i}$ the extent of emigration of group $i$ and $B_{i}$ is the biomass of group $i$.

In the Ecosim routine, the foraging arena theory states that prey are not always available to predators, but that interchange from vulnerable to invulnerable pools is based on the trade-off between the risks of being eaten and starving (Christensen et al., 2005). Hence, the quantity of prey $i$ consumed by predator $j$ (Qij) depends on the vulnerability $\left(v_{i j}\right)$, given by

$Q_{i j}=\left(a_{i j} \times v_{i j} \times B_{i} \times B_{j}\right) /\left(2 \times v_{i j} \times a_{i j} \times B_{j}\right)$,

where $a_{i j}$ is the effective search rate of predator $j$ feeding on prey $I, B_{i}$ the biomass of prey and $B_{j}$ is predator biomass. The rate at which prey moves from one pool to another is referred to as the vulnerability $\left(v_{i j}\right)$, and it represents the effect that a large increase in predator biomass would have on the predation mortality of a given prey. Low values $(<2.0)$ for the vulnerability ratio imply bottom-up control in the foodweb, whereas a high value (>2.0) implies top-down control. Values $\sim 1$ indicate that groups are close to their carrying capacity (Freire et al., 2008). The default vulnerability value in EwE is 2.0, which implies that a mixed flow control is driving the system (Walters et al., 1997; Christensen and Walters, 2004). EwE was run using values of $F$ [Equation (2)] equal to 1 in order to maintain the same fishing level as in 1986, and the model was validated with biomass and catch data for four compartments.

After running the model, the weighted sum of squared deviations (SS) was estimated by comparing the log of the observed and predicted biomass and the $\log$ of the observed and predicted catches. The estimated SS represents a goodness-of-fit measure for the model (low SS results imply a good fit), and it can be improved by manually altering the value of vulnerability $\left(v_{i j}\right)$ from the vulnerability matrix. This results in an improved fit (assessed graphically) and smaller SS values.

The observed values of proportional fishing were assessed by dividing the catches for 1986 (the reference year) by the catches for 2003 (data from FAO, 2000, 2006). These values were compared with the estimated values for proportional fishing by dividing catch data from 1986 by the estimated catches (calculated in EwE) for 2003. A Chi-squared test was used to compare the observed values of proportional fishing with the estimated values. If the null hypothesis is accepted, then the model is appropriate for describing the dynamics of the fisheries. All data required for EwE were gathered and standardized to units of $\mathrm{t} \mathrm{km}^{-2}$ or $\mathrm{t}$ $\mathrm{km}^{-2}$ year $^{-1}$. EwE version 5.1.152 was used.

\section{Dataset}

The Angolan ecosystem in 1986 was modelled by EwE using the main stocks described in the landings data for Angola, which were aggregated into 20 compartments chosen from Fish Stat Plus (FAO, 2000): Trachurus (represented by $T$. trecae, $T$. capensis and $T$. trachurus), Sardinella (S. aurita and Sardinella spp.), Sciaenidae, Ariidae, Merluccius (M. polli, M. capensis and Merluccius spp.), Dentex (D. angolensis and Dentex spp.), Pseudotolithus, Serranidae, Polynemidae, Parapenaeus longirostris, Haemulidae, Aristeu varidens, Small pelagics (Scomber japonicus, Stromateidae, Engraulis capensis, Chloroscombrus chrysurus, Sardinops sagax and another 11 functional groups), Mesopelagics (Katsuwonus pelamis, Sphyraena, Caranx hippos), Large pelagics (Thunus spp., Istiophoridae, and another four groups), Demersal fish (Pagellus bellottii, Pseudopeneus prayensis, Lepidopus caudatus and another 12 groups), Chondrichthyes (Raja and another five groups), Miscellaneous (Diplodus, Priachanthus, Cynoglossidae and another nine groups), Penaeus and Cephalopods (Loligo, Octopodidae, Octopus vulgaris and another seven groups). Other than cephalopods 
and shrimps, another eight groups represented the non-fish compartments: marine mammals, seabirds, macrobenthos, mesobenthos, large zooplankton, small zooplankton, phytoplankton and detritus.

Fish biomass $(B)$ in $1985 / 86$ was estimated (Strømme et al., 1986) from the results of six surveys carried out in January, April, August and November 1985 and January and April 1986. Pelagic stocks were assessed using acoustic integration and the results of targeted bottom and midwater trawls to identify species (Strømme et al., 1986). Pelagic species (carangids, barracudas) were estimated as basket species. Demersal stocks were assessed with the swept-area method. The individual biomass for each species was calculated using the total density of fish and the proportional composition of each species in the catch registered by the surveys carried out in four parts of the Angolan coast (Strømme et al., 1986).

The information required for the other main parameters of the EwE model (i.e. $P B$, production/biomass, and $Q B$, consumption/biomass) was obtained from FishBase (routine: Ecopath parameters) and Shannon et al. (2003). Diet compositions were taken from Heymans et al. (2004) and Fishbase (Froese and Pauly, 2007).

Given that the information for all non-fish compartments and diet compositions is not available in Angola, we used some approximations of $P B, Q B$ and $E E$ for the non-fish components of the Benguela system in general (Shannon et al., 2003). Consequently, EwE estimated $B$ values for phytoplankton, small and large zooplankton and macro- and microbenthos. For marine mammals and seabirds, we used a guesstimate of a very small biomass, and $P B$ and $Q B$ estimates were based on values for the whole Benguela system (Heymans $e t$ al., 2004).

The Angola EwE model for 1986 was run from 1986 to 2003, and was fitted for two available timeseries: 1986-2003 catch data (FAO, 2000 and 2006) on the four compartments (Sardinella, Trachurus, Dentex and Haemulidae), and biomass data for the same compartments from 1996 to 2003 (Duarte et al., 2005). Biomass data for the period 1996-2003 were estimated in a similar way to the biomass estimated for 1985/86 by Strømme et al. (1986) and described above. Our data for the Ecosim routine consisted in several types (described in Christensen et al., 2005): Type 1 (biomass between 1996 and 2003), Type 6 (catch between 1996 and 2003), Type 4 ( $F$, i.e. catch/biomass for the period 1996-2003) and Type -6 (forced catch between 1986 and 1995).

The results of the Angolan EwE model were compared with those for Namibia (northern Benguela for the 1980s; Heymans et al., 2004) and South Africa (southern Benguela for 1980 to 1989; Shannon et al., 2003), which were also built using an Ecopath modelling approach.

The ecosystems (or models) were compared in terms of estimated flows (consumption, production, respiration and throughput, which together represent the total flow) as well as ecosystem attributes: the Finn index, which indicates the recycled fraction of an ecosystem's throughput; the Finn mean path length, which is related to the recovery time of the system; the total primary production/total respiration rate, which indicates a mature ecosystem when it is close to a value of 1 (sensu Odum, 1969); connectivity and omnivory indices, which measure, in different ways, the intricacy of the system; and ascendancy and overhead (Ulanowicz, 1986), which are complementary despite the latter reflecting the system's reserves (Christensen, 1995).

The efficiency of fisheries (catches/net primary production) and the primary production required (PPR) to support each fishery, expressed as a percentage of primary production (Christensen and Pauly, 1995), were estimated for the Angolan marine system and compared with those of Namibia (Heymans et al., 2004) and South Africa (Shannon et al., 2003).

\section{RESULTS}

There was no decrease in the TLm of the Angolan landings over time $(T L m=3.3)$, despite the volume of the landings decreasing during the 1980s (Fig. 1a). The correlation between the TLm and the landings was weak (Fig. 1b; Spearman rank correlation, $\mathrm{r}_{\mathrm{s}}=-0.24$, $p=0.071)$. There was a significant correlation between the landings in Angola and Namibia $\left(\mathrm{r}_{\mathrm{s}}=0.71 ; p=0.000\right)$
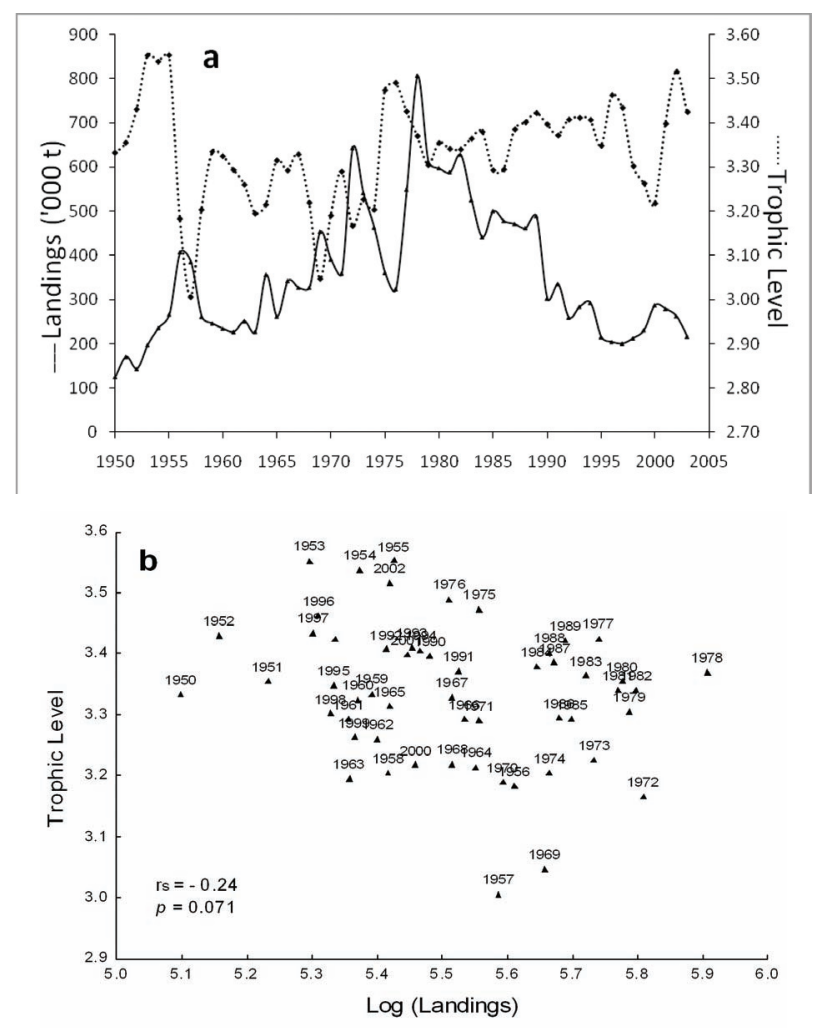

FIG. 1. - (a) Fishery landings and TLm (mean trophic level) in the Angolan marine ecosystem,1950 to 2003; (b) relationship between TLm and log landings. Data source: FAO $(2000,2006)$. 

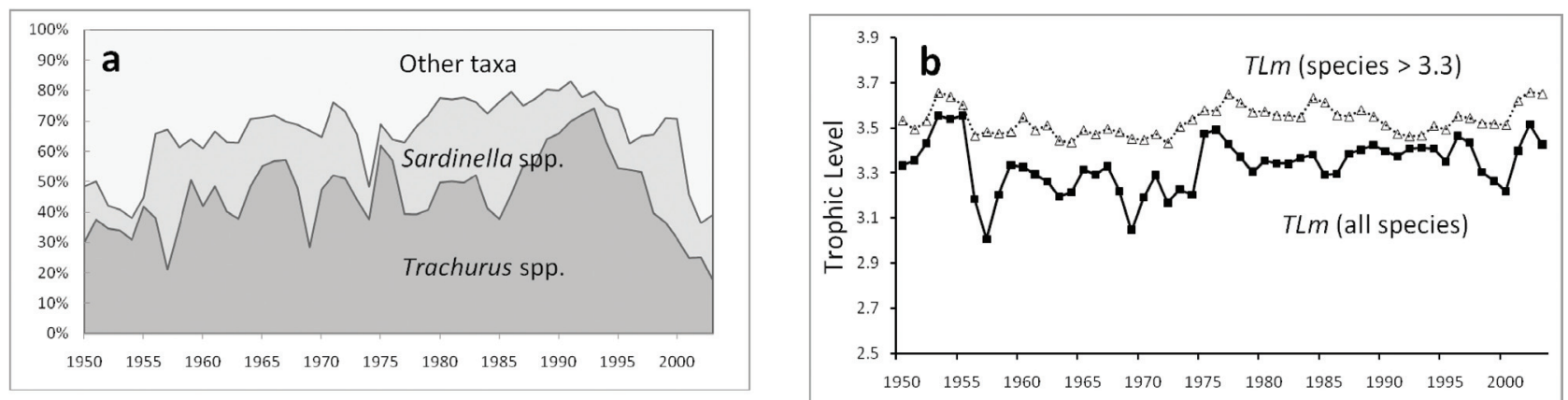

FIG. 2. - (a) Contributions by different groups to landings (\%) in the Angolan fishery; (b) mean trophic level calculated for all species and for species with a trophic level $>3.3$. Data source: FAO $(2000,2006)$.

TABLE 1. - Ecopath estimates of the trophic level (TL) and ecotrophic efficiency (EE) and the input parameters for the compartments in the ecosystem model of Angola (1986). $B$, biomass; $P / B$, production/biomass; $Q / B$, consumption/biomass; Vul, vulnerability values used in the Ecosim routine.

\begin{tabular}{|c|c|c|c|c|c|c|c|c|}
\hline No. & Group & $T L$ & $\begin{array}{c}B \\
\left(\mathrm{t} \mathrm{km}^{-2}\right)\end{array}$ & $\begin{array}{c}P / B \\
\left(\text { year }^{-1}\right)\end{array}$ & $\begin{array}{c}Q / B \\
\left(\text { year }^{-1}\right)\end{array}$ & $\mathrm{EE}$ & $\begin{array}{l}\text { Catch } \\
\left(\mathrm{t} \mathrm{km}^{-2}\right)\end{array}$ & Vul. \\
\hline 1 & Trachurus & 3 & 0.778 & 1.17 & 4.856 & 0.496 & 0.422 & 1.0 \\
\hline 2 & Sardinella & 2.82 & 0.778 & 2.7 & 12 & 0.509 & 0.428 & 2.0 \\
\hline 3 & Sciaenidae & 3.3 & 0.11 & 1.1 & 3.7 & 0.703 & 0.033 & 2.0 \\
\hline 4 & Ariidae & 3.79 & 0.042 & 1.35 & 6.4 & 0.988 & 0.023 & 2.0 \\
\hline 5 & Merluccius & 3.64 & 0.12 & 1.1 & 4.5 & 0.99 & 0.04 & 1.05 \\
\hline 6 & Dentex & 3.27 & 0.04 & 1 & 5 & 0.331 & 0.01 & 25.0 \\
\hline 7 & Pseudotolithus & 3.97 & 0.012 & 1.8 & 5.4 & 0.9 & 0.006 & 1.1 \\
\hline 8 & Serranidae & 3.4 & 0.079 & 1.1 & 2.5 & 0.99 & 0.006 & 2.0 \\
\hline 9 & Polynemidae & 2.99 & 0.013 & 2.24 & 6.8 & 0.771 & 0.008 & 2.0 \\
\hline 10 & Parapenaeus longirostris & 2 & 0.027 & 3 & 13.3 & 0.563 & 0.013 & 2.0 \\
\hline 11 & Haemulidae & 3.44 & 0.022 & 1.5 & 9 & 0.53 & 0.011 & 1.1 \\
\hline 12 & Aristeu varidens & 2 & 0.01 & 2.2 & 14.025 & 0.816 & 0.005 & 2.0 \\
\hline 13 & Small pelagics & 2.7 & 0.25 & 1.96 & 15 & 0.8 & 0.051 & 2.0 \\
\hline 14 & Mesopelagics & 3.3 & 0.2 & 0.92 & 6.7 & 0.793 & 0.002 & 2.0 \\
\hline 15 & Large pelagics & 3.6 & 0.02 & 0.63 & 5 & 0.8 & 0.006 & 2.0 \\
\hline 16 & Demersal fish & 3.37 & 0.016 & 2.7 & 10 & 0.79 & 0.008 & 2.0 \\
\hline 17 & Chondrichthyes & 4.32 & 0.007 & 0.9 & 3.5 & 0.8 & 0.004 & 2.0 \\
\hline 18 & Cephalopods & 3.47 & 0.001 & 2.5 & 6 & 0.8 & 0.001 & 2.0 \\
\hline 19 & Miscellaneous & 2.46 & 0.166 & 2.6 & 10 & 0.8 & 0.01 & 2.0 \\
\hline 20 & Penaeus & 2 & 0.013 & 3 & 19.2 & 0.8 & 0.002 & 2.0 \\
\hline 21 & Marine mammals & 4 & 0.01 & 0.04 & 19.9 & 0.00 & & 2.0 \\
\hline 22 & Seabirds & 3.52 & 0.01 & 0.4 & 65.7 & 0.00 & & 2.0 \\
\hline 23 & Macrobenthos & 2.16 & 0.378 & 4 & 19.7 & 0.767 & & 2.0 \\
\hline 24 & Mesobenthos & 2 & 0.858 & 3 & 35 & 0.75 & & 2.0 \\
\hline 25 & Large zooplankton & 2.6 & 0.401 & 30 & 150 & 0.600 & & 2.0 \\
\hline 26 & Small zooplankton & 2 & 1.300 & 50 & 200 & 0.610 & & 2.0 \\
\hline 27 & Phytoplankton & 1 & 3.601 & 65 & - & 0.890 & & \\
\hline 28 & Detritus & 1 & - & - & - & 0.898 & & \\
\hline
\end{tabular}

and a small correlation between those of Angola and South Africa $\left(\mathrm{r}_{\mathrm{s}}=0.51, p=0.000\right)$. The TLm for Angolan landings was 2.97 in 1986 (the reference year used in the EwE model) and 3.12 in 2003 (the final year of the simulation).

The relative dominance of Trachurus spp. in Angolan landings decreased from $60 \%$ in the 1980 s to $40 \%$ in 2003, with Sardinella spp. remaining constant at $20 \%$ and the other taxa increasing from 15 to $40 \%$ (Fig. 2a). In Namibia over the same two decades, Trachurus $t$. capensis increased in relative importance from 40 to $55 \%$, Merluccius spp. remained at $\sim 25 \%$, and Sardinops sagax decreased in importance from 10 to $6 \%$. In South Africa, Engraulis encrasicolus decreased in importance from 45 to 25\%, Merluccius spp. remained at $\sim 24 \%$, and S. sagax increased from 7 to $25 \%$. The TLm in the Angolan landings did not decrease over time (Fig. 2b). In fact, when estimated for fish stocks with a value $>3.3$, the TLm remained consistently high.

The catch time-series for Angola was available for 53 years (Fig. 1). The ten largest annual landings were between 1972 and 1985, during a period of 14 years. At that time, the predators $(T L>3.3)$ represented $64.4 \%$ (s.d. $4.7 \%$ ) of the total landings. Of the ten smallest annual landings there were four in the 1950s (four low landings), 1961, 1995-1997 and 2003. In these catches, the same group $(T L>3.3)$ constituted $75.6 \%$ (s.d. $11.65 \%$ ) of the catches. Each of the main stocks described in the landing data for Angola was represented by a single compartment in the preliminary EwE model (components 1 to 20, Table 1). The diet matrix used is shown in Appendix 2.

The global output of the Angolan model and comparisons with the Namibian and South African models 


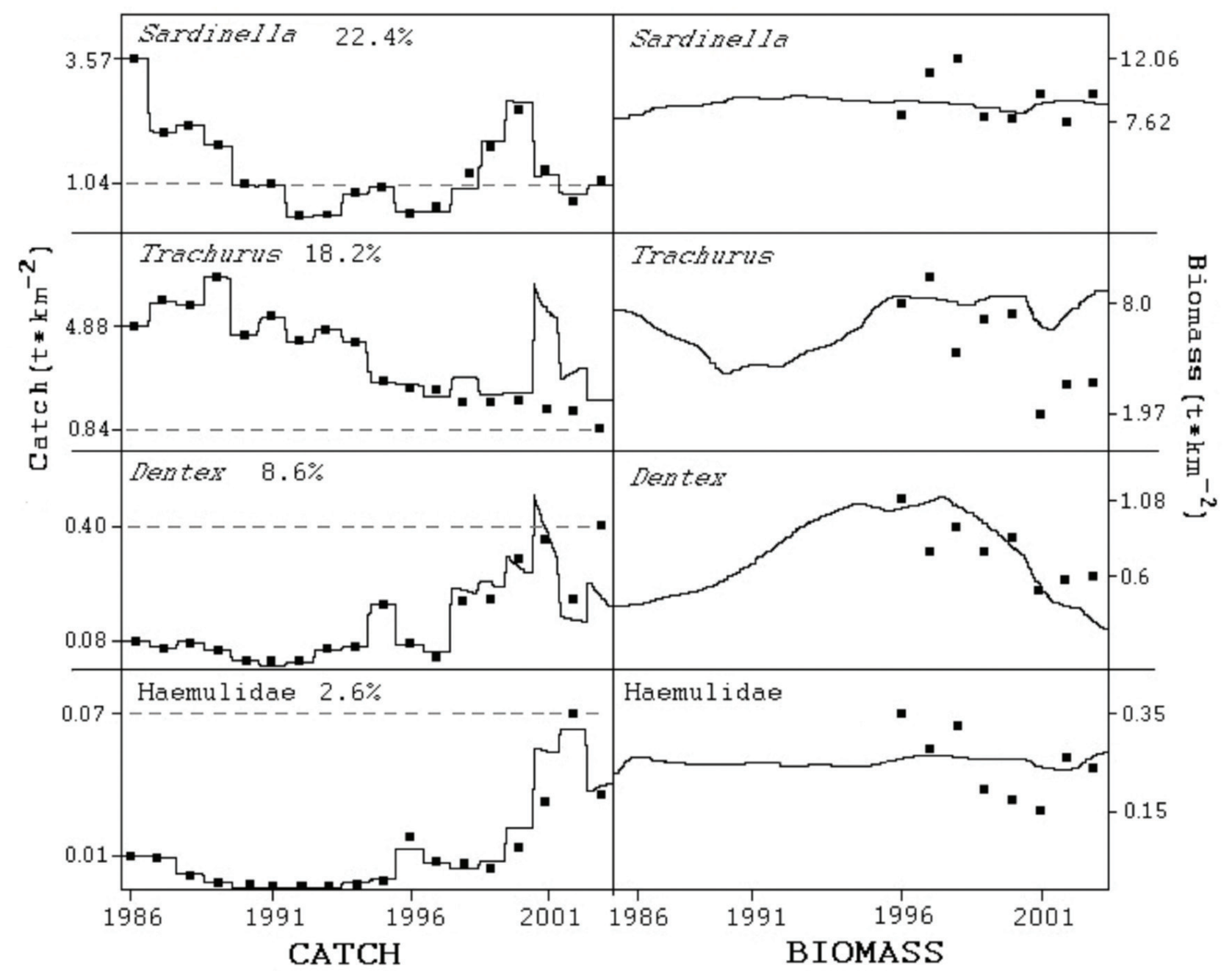

FIG. 3. - Catch (left panels) and biomass (right panels) for the main fishing groups in the Angolan model. Dots are observed values and lines simulated values (catch data from FAO, 2000, 2006; biomass data from Duarte et al., 2005). Percentage values are presented in relation to total landings in 2003.

are listed in Table 2. It is clear that the Angolan system is less productive in terms of biomass than the other two, but the resilience in the three ecosystems is the same.

SS values for the EwE model fits varied from 1076.43 for the first trial, when all the vulnerability values were set to 2.0 (default), to a minimum of 7.6 using the following alterations in the vulnerability values of the consumers (Table 2): Trachurus (1.0), Merluccius (1.05), Pseudotolithus (1.1) and Haemulidae (1.1). This indicates that these groups were close to their carrying capacities (a value of 1.0), and that they are subject to bottom-up control, which does not influence their prey. In contrast, the vulnerability values for Dentex were 25.0, which indicates that the group probably has a top-down effect on its prey. Figure 3 depicts the catch and biomass observed and estimated by the Angolan model using new vulnerability values (Table 1), $F=1$, which results in $\mathrm{SS}=7.6$.

The $\chi^{2}$ test used to compare the values of proportional fishing (observed vs estimated; Table 3 ) allowed the null hypothesis to be rejected $\left(\chi^{2}=53.6, p<0.001\right)$, i.e. the estimated values were different from the observed values. However, if the Pseudotolithus compartment is removed from the analysis, the null hypothesis can be accepted $\left(\chi^{2}=18.3 ; p=0.44\right)$ and the model is then appropriate for describing the dynamics of the landings.

\section{DISCUSSION}

There are some key constraints to our analysis. First, the collection of fishery statistics in Angola was hampered by internal conflict (i.e. war) for three decades (from 1972 to 2002). In addition, the expansion of small-scale fisheries increased the difficulties in data collection because these fisheries are spread out widely, and consequently regularly go unreported. However, the landings data for Angola (FAO, 2000, 2006) followed a similar trend to that of other fisheries, by initially increasing but then decreasing (central Chile, Arancibia and Neira, 2005; UK, Thurstan et al., 2010). In our opinion, it is reasonable to assume that 
TABLE 2. - Ecosystem indicators calculated by Ecopath describing the system of Angola (1986) and comparing it with the northern Benguela system - Namibia (Heymans et al. 2004) and the southern Benguela system - South Africa (Shannon et al. 2003).

\begin{tabular}{|c|c|c|c|}
\hline Parameter & $\begin{array}{c}\text { Angola } 1986 \\
\left(5-17^{\circ} \mathrm{S} ; \text { this paper }\right)\end{array}$ & $\begin{array}{c}\text { Namibia 1980-1989 } \\
\text { (northern Benguela; } \\
\text { Heymans et al., 2004) }\end{array}$ & $\begin{array}{l}\text { South Africa 1980s } \\
\text { (southern Benguela; } \\
\text { Shannon } \text { et al., 2003) }\end{array}$ \\
\hline \multicolumn{4}{|l|}{ Summary statistics } \\
\hline Trophic level of fishery & 2.97 & 3.25 & 4.74 \\
\hline Efficiency of fishery & 0.005 & 0.0009 & 0.00025 \\
\hline Total landings & 1.1 & 6.7 & 3.04 \\
\hline Primary production required, PPR & 34.9 & 5.9 & 4.4 \\
\hline Total biomass (excl. detritus) & 9.279 & 360.6 & 221.0 \\
\hline Total net primary production & 234.0 & 7319.0 & 11974.0 \\
\hline Total consumption & 381.62 & 11742.6 & 17230.0 \\
\hline Total export & 14.72 & 1221.2 & 2559.0 \\
\hline Total respiration & 219.3 & 1713.1 & 9416.0 \\
\hline Total production & 319.0 & 10036.0 & 16233.0 \\
\hline Throughput & 752.0 & 23495.0 & 37975.0 \\
\hline Net production & 14.72 & 1249.1 & 2559.0 \\
\hline Total flows to detritus & 136.7 & 4460.8 & 8771.0 \\
\hline Connectance index & 0.174 & 0.285 & 0.23 \\
\hline Systems omnivory index & 0.196 & 0.196 & 0.234 \\
\hline \multicolumn{4}{|l|}{ Attributes } \\
\hline Total primary production/total respiration & 1.01 & 1.20 & 1.27 \\
\hline Total primary production/total biomass & 25.22 & 20.3 & 54.2 \\
\hline Total biomass/throughput & 0.012 & 0.015 & 0.006 \\
\hline Finn cycling index & 13.5 & 22.1 & 18.2 \\
\hline Ascendancy ( $\%$ of capacity) & 24.5 & 24 & 21 \\
\hline Overhead (\% of capacity) & 75.5 & 76 & 79 \\
\hline Finn mean path length & 3.2 & 3.2 & 3.17 \\
\hline
\end{tabular}

TABLE 3. - Catch observed in 1986 and 2003 for groups in the Angola ecosystem $\left(\mathrm{km}^{-2}\right)$, and relative and accumulated proportions of landings in 2003. Relative observed fishing in 1986/2003 and calculated fishery 1986/2003 by Ecopath with Ecosim were compared with the Chi-squared test. The result was $\chi^{2}=53.6(p=0.00)$, but if the Pseudotolithus compartment was removed, $\chi^{2}=18.3, p=0.44$ (see text).

\begin{tabular}{|c|c|c|c|c|c|c|c|}
\hline No. & Group & Catch 1986 & Catch 2003 & $\begin{array}{l}\text { Relative \% } \\
\text { (2003) }\end{array}$ & $\begin{array}{c}\text { Proportion observed, } \\
1986 / 2003\end{array}$ & $\begin{array}{c}\text { ProportionEcopath, } \\
1986 / 2003\end{array}$ & $\chi^{2}$ \\
\hline 2 & Sardinella & 0.428 & 0.104 & 22.36 & 0.243 & 0.26 & 0.001 \\
\hline 1 & Trachurus & 0.422 & 0.085 & 18.20 & 0.201 & 0.46 & 0.145 \\
\hline 13 & Small pelagics & 0.051 & 0.042 & 9.06 & 0.824 & 1.03 & 0.041 \\
\hline 7 & Pseudotolithus & 0.006 & 0.042 & 9.00 & 7.0 & 1.03 & 34.6 \\
\hline 3 & Sciaenidae & 0.033 & 0.04 & 8.70 & 1.21 & 0.91 & 0.100 \\
\hline 6 & Dentex & 0.01 & 0.04 & 8.66 & 4.0 & 2.56 & 0.81 \\
\hline 16 & Demersal fish & 0.008 & 0.02 & 4.28 & 2.5 & 0.91 & 2.78 \\
\hline 19 & Miscellaneous & 0.01 & 0.016 & 3.43 & 1.6 & 0.99 & 0.37 \\
\hline 4 & Ariidae & 0.023 & 0.014 & 2.97 & 0.61 & 1.08 & 0.20 \\
\hline 11 & Haemulidae & 0.011 & 0.012 & 2.62 & 1.091 & 3.33 & 1.50 \\
\hline 8 & Serranidae & 0.006 & 0.011 & 2.42 & 1.83 & 1.03 & 0.63 \\
\hline 9 & Polynemidae & 0.008 & 0.01 & 2.05 & 1.25 & 0.93 & 0.11 \\
\hline 17 & Chondrichthyes & 0.004 & 0.008 & 1.80 & 2.0 & 0.97 & 1.1 \\
\hline 18 & Cephalopods & 0.001 & 0.004 & 0.94 & 4.0 & 0.94 & 9.96 \\
\hline 10 & P. longirostris & 0.013 & 0.0037 & 0.79 & 0.285 & 1.03 & 0.54 \\
\hline 20 & Penaeus & 0.002 & 0.0036 & 0.76 & 1.8 & 1.02 & 0.60 \\
\hline 12 & Aristeus varidens & 0.005 & 0.0034 & 0.73 & 0.68 & 1.0 & 0.102 \\
\hline 14 & Mesopelagics & 0.002 & 0.002 & 0.47 & 1.0 & 0.95 & 0.002 \\
\hline 15 & Large pelagics & 0.006 & 0.0019 & 0.42 & 0.316 & 1.04 & 0.50 \\
\hline \multirow[t]{2}{*}{5} & Merluccius & 0.04 & 0.0015 & 0.33 & 0.038 & 0.43 & 0.36 \\
\hline & All groups & 1.1 & 0.46 & & & & 54.4 \\
\hline
\end{tabular}

trends in the dataset are representative of the real situation because there are strong and significant correlations between the landings in Angola and those of the other two countries of the region, which exploit some shared stocks under the effect of the same major ocean current (the Benguela), and for which the fishery data are considered reliable.

Another source of bias in our analysis was the assumption of constant values of $T L$ for fish species during the study period, because quantitative information on gut contents was not produced in Angola during the years of data collection used here. Accordingly, there is great uncertainty in the dietary composition data used in the EwE model, which in our analysis were based on the available literature for the whole Benguela upwelling ecosystem, a system that encompasses just the southern coastal area off Angola (Heymans et al., 2004). Moreover, grouping species under a higher taxonomic unit would modify the estimates of $T \mathrm{Lm}$ and decrease the effect of fishing on the marine foodweb (Pauly et al., 2002). Nevertheless, the trends in the TLm for Angolan landings (i.e. no decrease) had 
similar dynamics to those in southern and northern Benguela ecosystems, where the values of TLm remained at 3.7 from 1975 to 2004 (Shannon and van der Lingen, 2006). The phenomenon of "fishing down the foodweb" did not take place at Mexican marine waters where decreases in the TLm were not detected (Pérez-España et al., 2006). However, such a result does not indicate that there is no depletion in Mexican fisheries or that fishing does not cause communitywide changes (Aburto-Oropeza et al., 2007). In this respect, community trophic levels have been considered to be better ecological indicators than the landings TLm for analysing the effect of fishing on an ecosystem (Shannon et al., 2009). In 1986, the trophic level for the fish community in Angola (weighted by biomass in the EwE model, but excluding phytoplankton and zooplankton) was 2.52 , which indicates greater fishing effort on predators because the landings $T L m$ was higher (2.97) and remained high until $2003(T L=3.12)$.

Conversely, in terms of the negative correlation observed between the TLm and Angolan landings (Fig. 1b), for Uruguayan and Chilean landings the largest catches were made when the species with the highest trophic levels were caught (Milessi et al., 2005; Arancibia and Neira, 2005) and the TLm values declined at rates of 0.28 and 0.175 (without horse mackerel) per decade respectively. For Portugal too, the landings TLm declined at a lower rate, 0.05 per decade (Baeta et al., 2009), which is quite different from the situation off Angola, where the TLm fluctuated over five decades (Fig. 1a).

Although the abundance of Sardinella spp. and Trachurus spp. (the dominant groups) in Angolan landings decreased over the final ten years of the study period, they were not replaced in the catches by other species. As a consequence, the landings gradually became more multispecific (Fig. 2a), keeping catch levels small (around $240000 \mathrm{t}$ ), although some species had a high $T L(\sim 3.1)$. However, all our analyses of trends in Angolan fisheries dynamics carry the caveat of limited information, and therefore should be considered with caution.

\section{The preliminary EwE model and comparisons}

Any model is only as good as the data used to parametrize and validate it (Heymans et al., 2009). Given that we used information from another ecosystem, the EwE model for Angola has to be viewed with caution because the contrast with other ecosystems is based on general ecosystem attributes without highlighting the differences between the internal and external drivers of the various ecosystems (Shannon et al., 2008) or their exploitation levels (Moloney et al., 2005; Coll et al., 2006).

The main differences between our preliminary Angolan model and those for the northern and southern Benguela concern the magnitude of the values for the ecosystem attributes (Table 2). The other two
Benguela upwelling ecosystems had values around 30 to 170 times higher than the Angolan system, given that the primary production estimate for the Angolan model is uncertain and probably underestimated. The differences in primary production, manifested in the magnitude of the ecosystem's attributes, have also been recorded in other ecosystems (Coll et al., 2006; Shannon et al., 2009). The differences in the Angolan, South African and Namibian models were obvious for flows (consumption, export, throughput and flows to detritus), production (net and primary production) and total biomass. Therefore, the differences among the landings and the biomasses used as input data in this comparison were reflected in the outputs: large landings require large flows and the upwelling system has a greater gross production than the Angolan tropical system.

The ecosystem attributes were almost the same for the three models, especially in reference to resilience or system maturity (overhead). The northern and southern Benguela ecosystems had higher Finn cycling and connection indices, probably because the diet composition matrix was more detailed than that of Angola, which was a compilation of both matrices. This underscores the importance of performing this descriptive study to encourage the collection and supply of such basic data.

The similarities between the ecosystem attributes of the Angolan model in the 1980s and the other Benguela systems could be an artefact, because in the former model, we used some parameters from the other two models. However, the magnitudes of the flows among the models were different, and the correspondence between ecosystem structure could be real. This inference is supported by the statement that a system's development (flows and rates) is different from a system's growth or dimension (Ulanowicz, 1986).

There were no detectable differences between decades in the southern Benguela (Shannon et al., 2003), suggesting that the maturing of this ecosystem (sensu Odum, 1969) is either small or slow. In contrast, the northern Benguela has been affected by anthropogenic and physical changes over the past three decades (Heymans et al., 2004), and the more drastic changes in the 1990s were the result of a Benguela Niño, which could also have impacted the Angolan system, despite the counter-balance supplied by a Guinea Niño (Binet et al., 2001). Notwithstanding, there are currently no data for determining the extent to which external and environmental forcing events influenced the Angola system, especially in terms of catch per unit effort.

Owing to the lack of data, it was not possible to construct a model for the 1990s for Angola. Like the South African system, however, it seems that the Angolan ecosystem maintained its maturity until 2003, despite catches decreasing. This statement can be supported by the landings of the three main groups (Sardinella spp., Trachurus spp. and small pelagics, which represent $50 \%$ of the catches) remaining the same. The main change observed was the replacement of Merluc- 
cius by Pseudotolithus, both of which are top predators in the system.

The proportion of primary production required to support catches (PPR) in the Angolan marine ecosystem $(34.9 \%)$ was similar to that required in other shelf systems (Christensen and Pauly, 1995); however, in South African and Namibian marine ecosystems, PPRs are smaller than in other systems despite the high mean trophic level of the catch in these two countries (Shannon et al., 2003). However, it is important to note that the efficiency of the fisheries (catch/net primary production) was 5.5 times higher in Angola than it was in Namibia, and 20 times higher in Angola than in South Africa, probably because primary production was estimated to be smaller in Angola.

The Angolan model was unable to simulate the increase in catches from 1986 to 2003 of Pseudotolithus (seven times higher in 2003) and cephalopods (four times higher in 2003). As in 2003, Pseudotolithus represented just $9 \%$ of the total catch and cephalopods just $1 \%$. The first was removed using a Chi-squared test, and the null hypothesis was accepted, which confirms that the higher landings are more predictable (Heymans and Sumalia, 2007) and that the model's predictions are reasonable for the overall landings.

The results of the EwE runs showed that, in general, the Angolan ecosystem operates under a mixed control foodweb with a tendency for bottom-up control, because fitted vulnerability values were $<2.0$ for four compartments (Trachurus, Merluccius, Pseudotolithus and Haemulidae), and only one compartment (Dentex spp.) had vulnerability values $>2$. This suggests that the last group has top-down control on its prey. The other vulnerability values remained at a value of 2 (mixed control). Using these values, the model fit was improved without modification to the fishing mortality values, which indicates that the internal structure defined by the ecological interactions among components is probably more influential on the Angolan marine ecosystem than other drivers (such as fishing or the physical/chemical environment). Trophic flow controls (also described by means of vulnerability values) accounted for $40 \%$ of the variability of the stocks in the southern Benguela ecosystem (Shannon et al., 2004b), which has wasp-waist functioning (Shannon et al., 2008). Considering that phytoplankton, zooplankton, small pelagics and Sardinella are the main sources of prey for all five compartments listed above, it is important for future studies and models of the Angolan marine ecosystem to focus on the productivity of plankton and the pelagic ecosystem.

\section{Concluding remarks}

This analysis of Angolan landings and the Angola EwE model showed a pattern of ecosystem dynamics similar to the pattern elsewhere in the large Benguela Current marine ecosystem (of which Angola, Namibia and South Africa are a part). Under the assumption derived here that system flexibility is the same in the three environments, we conclude that the management strategies for Angolan, Namibian and South African fishing should be similar. This would imply the presence of system-wide processes in the three subregions, and that it is necessary for the three countries to work together collaboratively in terms of their fish stocks and related ecosystems, as well as in relation to the management strategies applied.

To improve the Angolan model presented herein it would be necessary in the future to carry out gut content studies, biomass estimates with a longer time series and obtain a better understanding of phytoplankton and zooplankton dynamics, which play a key role in the abundance of Sardinella spp. (the main landings in Angola), because the preliminary model suggested that the system is a mixed control system with bottom-up tendencies. In addition, exploratory approaches using the trophic model should ideally be designed to test hypotheses that aim to investigate biotic and abiotic mechanisms that may drive changes over time in the ecosystem and landings.

\section{ACKNOWLEDGEMENTS}

We thank Sergio Neira and Colleen Moloney for their valued suggestions during the preparation of the manuscript, and two anonymous referees whose inputs helped us improve the submitted paper. RA was supported by a CNPq (Research Brazilian Agency) scholarship during his Post-Doctorate programme at the University of Cape Town (South Africa) under the supervision of Colleen Moloney.

\section{REFERENCES}

Aburto-Oropeza, O., L.G. López-Lemus, G. Paredes, M. Reza, A. Sáenz-Arroyo and E. Sala. - 2007. Letter to Editor. Fish. Res., 85: 233-234.

Arancibia, H. and S. Neira. - 2005. Long-term changes in the mean trophic level of central Chile fishery landings. Sci. Mar., 69(2): 295-300

Baeta, F., M. J. Costa and H. Cabral. - 2009. Changes in the trophic level of Portuguese landings and fish market price variation in the last decades. Fish. Res., 97: 216-222.

Batty, M., M. Tjipute, M. Sowman, P. Cardoso and P. Fielding. 2005. Overview and analysis of socio-economic and fisheries information to promote the management of artisanal fisheries in the BCLME region - Namibia. Final Report and Recommendations (Namibia). 40 pp. http://www.eeu.org.za/thematic-areas/integrated-coastal-and-small-scale-fisheries-management/ benguela-current-large-marine-ecosystems/component-b

Béné, C. and S. Heck. - 2005. Fish and food security in Africa. NAGA, WorldFish C. Quart., 28(3-4): 8-13.

Binet, D., B. Gobert and L. Maloueki. - 2001. El Niño-like warm events in the Eastern Atlantic $\left(6^{\circ} \mathrm{N}, 20^{\circ} \mathrm{S}\right)$ and fish availability from Congo to Angola (1964-1999). Aquat. Liv. Res., 14: 99-113.

Caddy, J.F. and K.L. Cochrane. - 2001. A review of fisheries management past and present and some future perspectives for the third millennium. Ocean Coast. Mgmt, 44: 653-682.

Christensen, V. - 1995. Ecosystem maturity - towards quantification. Ecol. Mod., 77: 3-32.

Christensen, V. and D. Pauly. - 1992. A guide to the ECOPATH II program (version 2.1). ICLARM Software, 6. $72 \mathrm{pp}$.

Christensen, V. and D. Pauly. - 1993. Trophic models of aquatic 
ecosystems. ICLARM, Manila. $390 \mathrm{pp}$.

Christensen, V. and D. Pauly. - 1995. Primary production required to sustain global fisheries. Nature, 374: 255-257.

Christensen, V. and C. Walters. - 2004. Ecopath with Ecosim: methods, capabilities and limitations. Ecol. Mod., 172: 109-139

Christensen, V., C.J. Walters and D. Pauly. - 2005. Ecopath with Ecosim: a user's guide. Fisheries Centre, University of British Columbia, Vancouver, Canada. November 2005 version. 154 pp. (available online at www.ecopath.org)

Coll, M., L.J. Shannon, C.L. Moloney, I. Palomera and S. Tudela. -2006. Comparing trophic flows and fishing impacts of a NW Mediterranean ecosystem with upwelling systems by means of standardized models and indicators. Ecol. Mod., 198: 53-70.

Duarte, A., P. Fielding, M. Sowman and M. Bergh. - 2005. Overview and analysis of socio-economic and fisheries information to promote the management of artisanal fisheries in the BCLME region- Angola. Final Report and Recommendations (Angola). 112 pp. http://www.eeu.org.za/thematic-areas/ integrated-coastal-and-small-scale-fisheries-management/ benguela-current-large-marine-ecosystems/component-b

FAO. - 2000. FishStat Plus. Universal software for fisheries statistical time series. Version 2.3. FAO, Rome.

FAO. - 2006. Fishery and Aquaculture Statistics. Yearbook 2006. FAO, Rome. $81 \mathrm{pp}$

Freire, K.M.F., V. Christensen and D. Pauly. - 2008. Description of the East Brazil large marine ecosystem using a trophic model. Sci. Mar., 72(3): 477-491.

Froese, R. and D. Pauly (eds.). - 2007. FishBase. World Wide Web electronic publication. www. fishbase.org, version (02/2007)

Griffis, R.B. and K.W. Kimball. - 1996. Ecosystem approaches to coastal and ocean stewardship. Ecol. Appl., 6(3): 708-712.

Heymans, J.J. and U.R. Sumaila. - 2007. Update ecosystem model for the northern Benguela ecosystem, Namibia. In: W.J.F. Le Quesne, F. Arreguín-Sánchez and J.J. Heymans (eds.), INCOFISH Ecosystem models: Transiting from Ecopath to Ecospace. Fisheries Centre Research Reports, pp. 25-70. Fisheries Centre, Vancouver, Canada. http://www2.fisheries.com/ archive/publications/reports/report15 6.php

Heymans, J.J., L.J. Shannon and A. Jarre. - 2004. Changes in the northern Benguela ecosystem over three decades: 1970s, 1980s and 1990s. Ecol. Mod., 172: 175-195.

Heymans, J. J., U. R. Sumaila and V. Christensen. - 2009. Policy options for the northern Benguela ecosystem using a multispecies, multifleet ecosystem model. Prog. Oceanogr., 83: 417-425.

Milessi, A.C., H. Arancibia, S. Neira and O. Defeo. 2005. The mean trophic level of Uruguayan landings during the period 19902001. Fish. Res. 74: 223-231.

Moloney, C.L., A. Jarre, H. Arancibia, Y.M. Bozec, S. Neira, J-P. Roux and L.J. Shannon. - 2005. Comparing the Benguela and Humboldt marine upwelling ecosystems with indicators derived from inter-calibrated models. ICES J. Mar. Sci., 62: 493-502.

Odum, E.P. - 1969. The strategy of ecosystem development. Science, 104: 262-270.

Pauly, D., V. Christensen, S. Guenette, T.J. Pitcher, U.R. Sumaila, C.J. Walters, R. Watson and D. Zeller. - 2002. Towards sustainability in world fisheries. Nature, 418: 689-695.

Pauly D., V. Christensen, J. Dalsgaard, R. Froese and F. Torres. 1998. Fishing down marine food webs. Science, 279: 860-863.

Pérez-España, H., L.G. Abarca-Arenas and M.L. Jiménez-Badillo. 2006. Is fishing-down trophic web a generalized phenomenon? The case of Mexican fisheries. Fish. Res., 79: 349-352.

Pichevin, L., M. Cremer, J. Giraudeau and P. Bertrand. - 2005. A 190 ky record of lithogenic grain-size on the Namibian slope: forging a tight link between past wind-strength and coastal upwelling dynamics. Mar. Geog., 218: 81-96.
Polovina, J.J. - 1984. Model of a coral reef ecosystem. 1. The ECOPATH model and its application to French Frigate Shoals. Cor. Reefs, 3: 1-11.

Schwartzlose, R.A., J. Alheit, A. Bakun, T.R. Baumgartner, R. Cloete, R.J.M. Crawford, W.J. Fletcher, Y. Green-Ruiz, E Hagen, T. Kawasaki, D. Lluch-Belda, S.E. Lluch-Cota, A.D. MacCall, Y. Matsuura, M.O. Nevárez-Martínez, R.H. Parrish, C. Roy, R. Serra, K.V. Shust, M.N. Ward and J.Z. Zuzunanga. - 1999. Worldwide large-scale fluctuations of sardine and anchovy populations. S. Afr. J. Mar. Sci., 21: 289-347.

Shannon, L.J. and C. van der Lingen. - 2006. Ecosystem states, ecosystem changes and changes in ecosystem functioning of the southern and northern Benguela ecosystem. EAF Project Regional Meeting, Cape Town (SA). Document 3a. 15 pp.

Shannon, L.J., C.L. Moloney, A. Jarre and J.G. Field. - 2003. Trophic flows in the southern Benguela during the 1980s and 1990s. J. Mar. Sys., 39(1-2): 83-116.

Shannon, L.J., K.L. Cochrane, C.L. Moloney and P. Fréon. - 2004a Ecosystem approach to fisheries management in the southern Benguela: a workshop overview. Afr. J. Mar. Sci., 26: 1-8.

Shannon, L.J., V. Christensen and C. Walters. - 2004b. Modelling stock dynamics in the southern Benguela ecosystem for the period 1978-2002. In: L.J. Shannon, K.L. Cochrane and S.C. Pillar (eds.), Ecosystem Approaches to Fisheries in the Southern Benguela. Afr. J. Mar. Sci. 26: 179-196.

Shannon, L.J., S. Neira and M. Taylor. - 2008. Comparing interna and external drivers in the southern Benguela and the southern and northern Humboldt upwelling ecosystems. Afr. J. Mar. Sci., 30(1): 63-84.

Shannon, L.J., M. Coll and S. Neira. - 2009. Exploring the dynamics of ecological indicators using food web models fitted to time series of abundance and catch data. Ecol. Ind., 9: 1078-1095.

Strømme, T., G. Søtersdal, O. Alvheim and H. Ullebust. - 1986 Report on surveys of Angola's marine fish resources. January 1985 - June 1986. http://www.fao.org/wairdocs/FNS/AA041E/ AA041E00.HTM

Sumaila, U.R., G. Munro and H. Keith. - 2005. Benguela Current Comission. Economic Study. Report of the United Nations Office for Projects Services (UNOPS) and Benguela Current Large Marine Ecosystem (BCLME) Programme. Vancouver, Canada.

Thurstan, R.H., S. Brockington and C.M. Roberts. - 2010. The effects of 118 years of industrial fishing on UK bottom trawl fisheries. Nature Comms, doi: 10.1038/ncomms1013.

Ulanowicz, R.E. - 1986. Growth and Development: Ecosystem Phenomenology. Springer, New York.

Vaz-Velho, F., B.E. Axelsen, P. Barros and G. Bauleth-D'Almeida. - 2006 Identification of acoustic targets off Angola using general discriminant analysis. Afr. J. Mar. Sc. 28(3-4): 525-533.

Vosloo, M.C. - 2004. A comparative assessment of the impact of recreational and subsistence fishing on selected Eastern Cape estuarine ecosystems using the Ecopath modeling approach. MSc thesis, Univ. Port Elizabeth.

Walters, C., V. Christensen and D. Pauly. - 1997. Structuring dynamic models of exploited ecosystems from trophic mass-balance assessments. Rev. Fish Biol. Fish. 7: 139-172.

Worm, B., E.B. Barbier, N. Beaumont, J.E. Duffy, C. Folke, B.S Halpern, J.B.C. Jackson, H.K. Lotze, F. Micheli, S.R. Palumbi, E. Sala, K.A. Selkoe, J.J. Stachowicz and R. Watson. - 2006 Impacts of biodiversity loss on ocean ecosystems service. Science, 314: 787-790.

Scient. ed.: B. Roel.

Received March 8, 2010. Accepted September 22, 2010.

Published online March 10, 2011. 
APPEndix.1. - Trophic level (TL) of the 40 main species or groups landed in Angola from 1950 to 2003 (FAO, 2000, 2006). Source for the TLs: Fishbase (Froese and Pauly, 2007).

\begin{tabular}{|c|c|c|c|c|c|}
\hline Species/group & $T L$ & Habitat & Species/group & $T L$ & Habitat \\
\hline Argyrosomus hololepidotus & 3.5 & Bathypelagic & Panulirus & 2.6 & Demersal \\
\hline Ariidae & 3.6 & Demersal & Parapenaeus longirostris & 2.7 & Demersal \\
\hline Aristeus varidens & 2.3 & Pelagic & Penaeus & 2.7 & Demersal \\
\hline Brachydeuterus auritus & 3.03 & Bathypelagic & Polynemidae & 3.4 & Demersal \\
\hline Brachyura & 2.0 & Demersal & Pseudotolithus & 3.9 & Demersal \\
\hline Caranx hippos & 3.6 & Bathypelagic & Raja & 3.75 & Demersal \\
\hline Congridae & 3.4 & Demersal & Sardinella spp. & 2.85 & Pelagic \\
\hline Cynoglossidae & 3.2 & Demersal & Sardinops sagax & 2.43 & Pelagic \\
\hline Dentex angolensis & 3.4 & Demersal & Sciaenidae & 3.7 & Demersal \\
\hline Dentex sp & 3.4 & Demersal & Scomber japonicus & 2.8 & Pelagic \\
\hline Engraulidae & 2.9 & Pelagic & Sepiidae & 3.6 & Cephalopod \\
\hline Engraulis capensis & 2.96 & Pelagic & Serranidae & 4.0 & Demersal \\
\hline Haemulidae & 3.3 & Demersal & Thunnus obesus & 4.5 & Pelagic \\
\hline Lepidopus caudatus & 4.47 & Bathydemersal & Todarodes sagittatus & 3.2 & Cephalopod \\
\hline Lethrinidae & 3.8 & Bathypelagic & Trachurus & 3.48 & Bathypelagic \\
\hline Lithognathus mormyrus & 3.38 & Bathypelagic & Trachurus t. capensis & 3.47 & Bathypelagic \\
\hline Megalaspis cordyla & 4.39 & Bathypelagic & Trachurus trachurus & 3.64 & Bathypelagic \\
\hline Merluccius capensis & 4.3 & Bathydemersal & Trachurus trecae & 3.3 & Bathypelagic \\
\hline Merluccius polli & 4.3 & Bathydemersal & Umbrina canariensis & 3.0 & Demersal \\
\hline Pagrus & 3.7 & Bathypelagic & Zeus faber & 3.8 & Bathypelagic \\
\hline
\end{tabular}

ApPENDIX 2. - Diet composition for the Angolan Ecopath model (1986).

\begin{tabular}{|c|c|c|c|c|c|c|c|c|c|c|c|c|c|c|c|c|c|c|c|c|c|c|c|c|c|c|}
\hline & Prey $\backslash$ Predator & 1 & 2 & 3 & 4 & 5 & 6 & 7 & 8 & 9 & 10 & 11 & 12 & 13 & 14 & 15 & 16 & 17 & 18 & 19 & 20 & 21 & 22 & 23 & 24 & $25 \quad 26$ \\
\hline 1 & Trachurus & & & & & & & & & & & 0.10 & & & & & & & & & & 0.05 & & & & \\
\hline 2 & Sardinella & & & & 0.25 & 0.05 & & 0.10 & 0.15 & & & 0.20 & & 0.10 & & 0.20 & & & 0.05 & & & 0.05 & 0.10 & & & \\
\hline 3 & Sciaenidae & & & & & 0.06 & & & 0.10 & & & & & & & & & & & & & & & & & \\
\hline 4 & Ariidae & & & & & & & & & & & & & & & & & & 0.05 & & & & 0.05 & & & \\
\hline 5 & Merluccius & & & & & 0.04 & & 0.20 & & & & & & & & & & 0.25 & & & & 0.25 & & & & \\
\hline 6 & Dentex & & & & & & & 0.05 & & & & & & & & & & & & & & & & & & \\
\hline 7 & Pseudotolithus & & & & 0.05 & & & & & & & & & & & & & & & & & & & & & \\
\hline 8 & Serranidae & & & & & 0.10 & & 0.15 & & & & & & & & & 0.10 & & & & & & & & & \\
\hline 9 & Polynemidae & & & & & & & 0.10 & & & & & & & & & & & & & & 0.04 & & & & \\
\hline 10 & P. longirostris & & & & & & 0.05 & & & 0.25 & & & & & & & & & & & & & & & & \\
\hline 11 & Haemulidae & & & & & & & 0.10 & & & & & & & & & & & & & & & & & & \\
\hline 12 & Aristeu varidens & & & & & & & 0.20 & & & & & & & & & & & & & & & & & & \\
\hline 13 & Small pelagics & & & & 0.10 & 0.10 & 0.05 & & 0.10 & & & 0.20 & & & & 0.20 & & & 0.05 & & & 0.20 & 0.20 & & & \\
\hline 14 & Mesopelagics & & & & 0.20 & 0.10 & & & & & & & & & & 0.10 & & 0.25 & & & & 0.10 & & & & \\
\hline 15 & Large pelagics & & & & & & & & & & & & & & & & & 0.15 & & & & & & & & \\
\hline 16 & Demersal fish & & & & 0.05 & & & & & & & & & & & & & 0.10 & 0.05 & & & 0.05 & & & & \\
\hline 17 & Condrichtis & & & & & & & & & & & & & & & & & 0.05 & & & & & & & & \\
\hline 18 & Cephalopodes & & & & & & & & & & & & & & & & & & & & & & & & & \\
\hline 19 & Miscelaneous & & & 0.15 & 0.15 & & 0.05 & 0.10 & 0.10 & & & & & & & 0.10 & & 0.20 & 0.10 & & & 0.26 & 0.20 & & & \\
\hline 20 & Penaeus & & & & & & & & 0.10 & 0.10 & & & & & & & & & & & & & & & & \\
\hline 21 & Marine mammals & & & & & & & & & & & & & & & & & & & & & & & & & \\
\hline 22 & Marine birds & & & & & & & & & & & & & & & & & & & & & & & & & \\
\hline 23 & Macrobenthos & & 0.05 & 0.23 & 0.10 & & 0.20 & & 0.20 & 0.25 & & 0.25 & & & & & 0.30 & & 0.25 & & & & & 0.05 & & \\
\hline 24 & Middlebenthos & 0.05 & 0.05 & 0.20 & 0.10 & 0.15 & 0.25 & & 0.25 & 0.35 & & 0.25 & & & & & & & 0.15 & 0.10 & & & & 0.10 & & \\
\hline 25 & Large Zoo & 0.50 & 0.35 & 0.32 & & 0.20 & 0.30 & & & & & & & 0.20 & 0.50 & 0.20 & 0.30 & & 0.25 & 0.10 & & & 0.20 & & & \\
\hline 26 & Small Zoo & 0.15 & 0.15 & 0.10 & & 0.20 & 0.10 & & & & & & & 0.20 & 0.50 & 0.20 & 0.30 & & 0.05 & 0.20 & & & 0.25 & & & 0.60 \\
\hline 27 & Phytoplankton & 0.30 & 0.40 & & & & & & & & & & & 0.50 & & & & & & 0.30 & & & & 0.05 & 0.15 & 0.200 .70 \\
\hline 28 & Detritus & & & & & & & & & 0.05 & 1.00 & & 1.00 & & & & & & & 0.30 & 1.00 & & & 0.80 & 0.85 & 0.200 .30 \\
\hline & Sum & 1 & 1 & 1 & 1 & 1 & 1 & 1 & 1 & 1 & 1 & 1 & 1 & 1 & 1 & 1 & 1 & 1 & 1 & 1 & 1 & 1 & 1 & 1 & 1 & 1 \\
\hline
\end{tabular}

